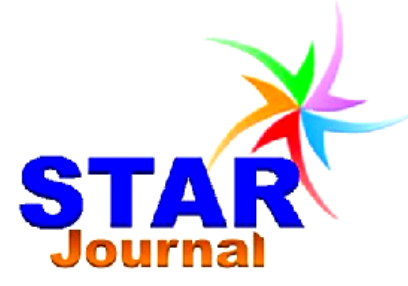

ISSN: 2226-7522(Print) and 2305-3327 (Online) Science, Technology and Arts Research Journal July-Sep 2012, 1(3): 59-67 www.starjournal.org

Copyright $\odot 2012$ STAR. All Rights Reserved

Review Article

\title{
Implementation of Instructional Supervision in Secondary School: Approaches, Praspects and Problems
}

\author{
Manas Ranjan Panigrahi \\ Department of Pedagogical Sciences, College of Education and Behavioural Sciences, \\ Haramaya University, Ethiopia
}

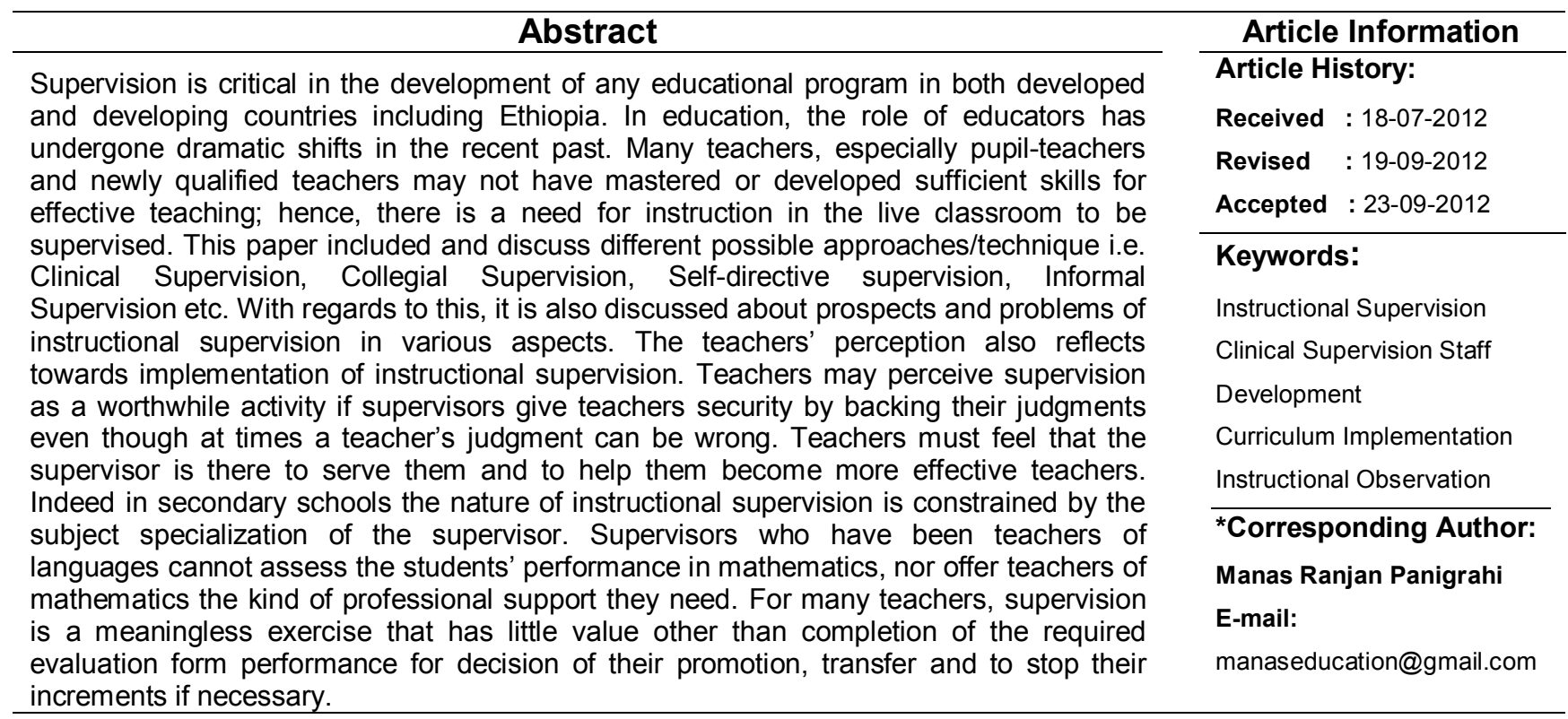

\section{INTRODUCTION}

Supervision is critical in the development of any educational program in both developed and developing countries including Ethiopia. In education, the role of educators has undergone dramatic shifts in the recent past. Many teachers, especially student teachers and newly qualified teachers may not have mastered or developed sufficient skills for effective teaching; hence, there is a need for instruction in the classroom to be supervised.

In Ethiopia the forces that brought about the need for supervision of instruction in the school system of the country include: Because we have very large classes, an increase in the numbers of secondary school pupils and the scope of secondary education; to improve the deteriorated quality of education, there is shortage of certified teachers, to help teachers in the classroom activities, has brought with it instruction problems which provide strong evidence of the need for supervision of instruction. Gaps in teachers' methodological knowledge have been well documented in the other parts of the world (Ball and MacDiarmid, 1990). The secondary school teachers of today have more difficult instructional problems to deal with in such matters as the method and material of instruction for widely different pupils. The above variables which paved the need for quality supervision became a motto to improve instruction in today's primary and secondary schools of the country's education system.

Nakpodia (2006) asserts that, instructional supervision in the modern era centers on the improvement of the teaching-learning situation for 


\section{Manas Ranjan Panigrahi}

the benefits of both the teachers and learners, helps in the identification of areas of strength and weaknesses of teachers, follow-up activities that should be directed at the improvement of identified areas of teachers' weaknesses and give recognition to the teachers and create a cordial working atmosphere based on good human relations. Moreover, it helps the teachers in terms of self-discovery particularly in the areas of improvisation and use of modern teaching aids as a basis for improving teaching strategies.

Fullan (2006) have underscored the critical importance of supervision role in high-quality instruction and its systematic delivery as most necessary in order to ensure continuous improvement and ongoing academic success.

However, the existing supervisory program exercised in Harari region is inadequate in many respects, ranging from its highly centralized administration to the rigidity of its practice. Supervisors who were appointed was had little or no background on educational administration and management. They had inadequate formal training on the techniques, concept and practice of supervision. The researcher had been working as district supervisor in Harari region and experienced many complaints from teacher and other stakeholders about the inefficiency of supervision services practiced in secondary schools. Practicing supervisors of secondary schools challenge many problems while providing support service effectively and efficiently to their staff members due to lack of training on supervision principles and skills, excessive workload, supervisors attitudinal and procedural, and guidance that are required to perform the complex functions of their position as cited in educational supervision manuals (MOE, 1987).

Indeed in secondary schools the nature of instructional supervision is constrained by the subject specialization of the supervisor. Supervisors who have been teachers of languages cannot assess the students' performance in mathematics, nor offer teachers of mathematics the kind of professional support they need. For many teachers, supervision is a meaningless exercise that has little value other than completion of the required evaluation form performance for decision of their promotion, transfer and to stop their increments if necessary.

Various scholars define supervision differently. To mention few, Sergiovanni and Starrat (1983) define supervision as a "... set of activities and role specifications designed to influence instruction". Ben Harris is quoted by Sergiovanni
Sci. Technol. Arts Res. J., July-Sep 2012, 1(3): 59-67

and Starrat (1985) as saying that “... supervision of instruction is directed towards both maintaining and improving the teaching-learning processes of the school". Neter and Krey (1971) in Egwunyenga (2005) defined supervision the phase of school administration which focuses primarily upon the achievement of the appropriate instructional expectations of the educational system. Supervision is a critical examination and evaluation of a school as a designated place of learning so as to make it possible for necessary advice to be given for the purpose of school improvement. Supervision of instruction is that process which utilizes a wide array of strategies, methodologies and approaches aimed at improving instruction and promoting educational leadership as well as change (Glanz and BeharHorenstein, 2000).

What is more, "Instructional supervision is a behavior system in school operation with distinct purpose, competences and activities which is employed to directly influence teaching behavior in such away as to facilitate student learning" (Lovell and Wiles, 1983). A comprehensive definition of supervision offered by Robert and Peter (1989), as supervision is instructional leadership that relates perspectives to behavior, clarifies purpose, contributes to and support organizational actions, coordinates interactions, provides for maintenance and improvement of instructional program, and assesses goal achievement. Furthermore, Mohanty (1994) defined this concept with reference to dictionary of education "All efforts of designated school officials, toward providing leadership to teachers and other education workers in the improvement of instruction, involve stimulation of professional growth and development of teachers, the selection and version of educational objectives, material of instruction, and methods of teaching and the evaluation of instruction.

\section{Approaches/techniques of Instructional Supervision}

Supervisors/ Principals struggle to sort out those aspects of schooling that need to be kept more or less uniform and those aspects that call for diversity and supervisors should match appropriate supervisory approaches to teachers' level of development needs. Teachers can play key role in deciding which of the options make sense to them given their needs at the time.

\section{Clinical supervision}

Acheson and Gall (1977) and Haileselassie (1997), quoted clinical supervision refers to faceto- face contact with the supervisor and the teacher intent of improving instructions and 


\section{Manas Ranjan Panigrahi}

increasing professional growth. It is assumed that a one- to one correspondence exists between improving classroom instruction. Cogan (1973), explained clinical supervision is "the rational and practical designed to improve the teachers classroom performance. It takes its principal data from the events of the classroom. The analysis of this data and the relationship between teacher and supervisor from the program, procedures and strategies designed to improve the students learning and improving the teacher's classroom behavior. Clinical supervision as a process for developing responsible teachers who were able to evaluate their own instruction, who were willing to accept criticism and use it for change, and who knew where they were headed in their own professional growth.

Beach and Reinhartz (2000) indicated "if schools are to improve the quality of instruction, it will be at the local building with the teacher at the heart of the improvement process (productivity through people)". The focus of clinical supervision is on formative evaluation, which is intended to increase the effectiveness of ongoing educational programs. It involves several phases which range from the initial planning of the lesson with the supervisor through to the conference phase and lastly, planning for the next lesson to be observed. However, the phases will depend on the nature of classroom activities, the time factor and the beliefs of the teacher and of the supervisor. Goldhammer (1969), proposed the following five-stage process in clinical supervision.

\section{- Pre-observation Conference}

According to Lovell and wiles (1983), the preobservation conference (behavior system) provides an opportunity for the supervisor and the teacher to establish relationship mutual trust and respect. The teacher and supervisions get to know each other as fellow professionals. So that it is essential to the establishment of the foundation for the observation and analysis of teaching. This approach is most suitable because the expertise, confidence, and credibility of the supervisor clearly outweigh information, experience, and capabilities as cited by (Glickman et al., 1998).

\section{- Classroom Observation}

In this stage the supervisors observes the teacher at work during formal lesson. Observation creates opportunities for the supervisor to help her/his test reality, the reality of his/her own perceptions and judgments about teaching. Acheson and Gall (1997) agree that the
Sci. Technol. Arts Res. J., July-Sep 2012, 1(3): 59-67

selection of an observation instrument will help sharpen the teacher's thinking about instruction. The conditions under which observations are made are very important to the teacher. Most teachers prefer the supervisor to notify them of the visit so that they can prepare their lessons. Indeed Goldhammer (1980) proposes, "If supervisors were to spend more of their energy in the classroom visits followed by helpful conference, we believe that teacher would probably have more friendly attitudes toward supervision". There is no other equally important choice than classroom visits for the betterment of instructions. Classroom observation is a valuable means to obtain first hand information and experience of the classroom atmosphere.

\section{- Analysis of the Observations}

As soon as the observation has been conducted, the supervisor organizes their observation data into clear discipline for feedback to the teacher. Collect, analyze, and present data gathered during classroom observations for post observation conferences, with the goal of strengthening instruction to improve student achievement (Glickman and others, 2000 and Zepeda, 2007).

\section{- Post-observation Conference}

In this stage the major purpose of supervisor is to give feedback to the teacher about the teacher's performance. Research demonstrates that teachers are likely to change their instructional behaviors on their own after their classroom has been described to them by a supervisor. Whether or not any positive change occurs depends on the quality of feedback that is provided (Sullivan and Glanz, 2002).

\section{- Post-conference Analysis}

The final phase in the clinical model is an evaluation of the process and outcome. It is a means of self improvement for the supervisor. It is the time when the supervisor assesses the nature of communication during conference, the effectiveness of the strategies used, the role of the teacher during the conference and the extent to which progress was made on the issue that were discussed. In supporting this stage Reavis (1978), stated the supervisor must see his role as trying to help teachers achieve purpose in more effective and efficient way.

\section{Collegial Supervision}

Several authors in the field of supervision propose collegial processes as options for supervision of teachers (Glatthorn, 1990; 
Manas Ranjan Panigrahi

Sergiovanni and Starratt, 1993; Sullivan and Glanz, 2000). Glatthorn describes cooperative professional development as a process of fostering teacher growth through systematic collaboration with peers and includes a variety of approaches such as professional dialogue, curriculum development, peer observations and feedback, and action research projects. Supervisors help to coordinate the collegial teams and monitor the process and goal attainment. Other terms that describe forms of collegial supervision include mentoring, cognitive coaching, and peer coaching.

In this option supervisor's role is that of active participation in working with the teacher. It can start with the lesson planning phase and goes through the whole process of teaching learning process. The supervisor and the teacher can engage in a sort of action research whereby they pose a hypothesis experiment and implement strategies towards reasoned solutions (Gebhard, 1990). Gebhard, quoting Cogan, states that teaching in mostly a problem- solving process that requires a sharing of ideas between the teacher and the supervisor.

\section{Informal Supervision}

Informal supervision is comprised of causal encounters that occur between supervisors and teachers and is characterized by frequent informal visits to teacher's classroom, conversation with teachers about their work, and other informal activities. Typically no appointments are made and classroom visits are not announced. In selecting additional options, supervisors should accommodate teacher preferences and honor them in nearly every case.

\section{Self- Directive Supervision}

Self-directed supervision is another current model of supervision (Sergiovanni and Starratt, 1993). In this approach, teachers set goals for their own professional development and present a plan for achieving these goals to a supervisor. At the end of a specified period of time, the teacher and supervisor conference to review data that represents the teacher's work toward the goal and reflect upon what was learned before setting a new set of goals. Others refer to this as goal-setting or performance-objectives models. This model describes idea of helping the teacher is seen as one that makes the supervisor as a 'Know- all' and the supervisee as a seeker of help. Fanselow (1990) starts by exploring of there could be amore reasoned method of benefiting a teacher in training. He proposes that teachers should try to see teaching differently by
Sci. Technol. Arts Res. J., July-Sep 2012, 1(3): 59-67

observing others teach or discussing their own teaching with others. Thus concludes that whereas the usual aim of observation and supervision is to help or evaluate the person being seen, the aim the author prose is self exploration, Seeing one's own teaching differently, observing others or ourselves to see teaching differently is not the same as being told what to do by others. Observing to explore is a process; observing to help or evaluate is providing a product.

\section{Prospects of Instructional Supervision}

A more humanistic explanation of supervision was given by Beach and Reinhartz (2000) in which instructional supervision needed to be viewed as a process that centers on instruction and provides teachers with feedback on their teaching so as to strengthen instructional skills to improve performance. Thus, the purpose of instructional supervision is to focus on teachers' instructional improvement which, in turn, improves student academic achievement.

\section{Supervision as a Means to Improvement of Instruction}

One of the major components of supervision is the improvement of instruction (Beach and Reinhartz, 2000; Glickman and others, 1998; Sergiovanni and Starratt, 1998). For instruction to improve, staff development, self-evaluation, and fostering curriculum development must be included in the supervisory processes. According to Calabrese and Zepeda (1997) supervision is "linking the facilitation of human growth to that of achieving goals. One way that in which the school as an organization can grow can be achieved through teacher development. According to Wanzare and Da Costa (2000), who cite others, there are four key strategies for enhancing the professional growth of teachers which include: First, the establishment and subsequent administrative support of and provision guidance for a systematic, ongoing staff development program (Starratt, 1997) supported by modeling, coaching, and collaborative problem solving should focus on means of linking new knowledge, on way of thinking, and on practice given existing knowledge, experience, and values (Glickman et al., 1997). Time needs to be provided for teachers to undertake professional development as part of their normal teaching responsibilities. Second, argue that teachers need to engage, both individually and in group, in the concrete tasks of teaching, observation, assessment, experimentation, and pedagogical reflection. In this way they will better understand the learning and development process given their 


\section{Manas Ranjan Panigrahi}

teaching contexts and students (Darling-Hammon and McLaughlin, 1995).

Third, given the wide variety of supervisory techniques described, supervisors should match appropriate supervisory approaches to teachers' level of development needs. The ultimate goal of supervisors should be to enable teachers to be self-directed (Glickman et al., 1997). Fourth, organizational leaders should work to establish a culture that values professional, collegial interactions among participants (e.g., team planning, sharing, evaluation, and learning to create methods for peer review of practice). In doing so, they promote the spread of ideas and shared learning (Darling-Hammond and McLaughlin, 1995). There exist many different avenues for providing direct assistance to teachers for the improvement of instruction. According to Zepeda and Ponticell (1998), teachers' perceptions of supervision were positive when supervision was viewed as coaching. They reported the value of coaching as such: What was coaching? The supervisor worked alongside the teacher, providing assistance while the teacher addressed his or her classroom concerns. The supervisor took an interest in the teacher's accomplishments during the process of change and improvement.

The supervisor provided evidence of success together with guidance to enable the teacher to build upon success. The supervisor was invested in the individual teacher's success. The supervisor was responsive to the individual teacher's needs and recognized that the supervisor's interactions with the teacher influenced the teacher's success. Coaching in its purest form is composed of planning, observing instruction, and reflecting the basic phases of all instructional supervisory models. One can glean that the goal of coaching is to assist teachers in becoming more resourceful, informed, and skillful professionals (McGreal, 1995). Costa and Garmston (1994) stated, "Skillful cognitive coaches apply specific strategies to enhance another person perceptions, decisions, and intellectual functions. Changing these inner thought processes is a prerequisite to improving overt behaviors that, in turn, enhance student learning".

\section{Staff Development}

The quality of student learning is directly related to the quality of classroom instruction. Therefore, one of the most important aspects of instructional leadership is to provide the necessary climate to promote ongoing instructional improvement. Supervisor is
Sci. Technol. Arts Res. J., July-Sep 2012, 1(3): 59-67

responsible to identity the training needs of the teachers and organize in-service programs in the form of work shop, seminars, conference, faculty meeting, intra school and inter school visits and other services are useful to be utilized, so as to realize effective staff professional development (Musazi,1987) and supervision manual (MOE,1994). According to Sergiovanni and Starrat (1998) stated, "since teachers often will not know-how to do what needs to be done, it is important for a supervisors to identify their needs and then to in-service them in the some ways".

Travers (1995) proposed the name of training is staff development, which primarily aim to increase the knowledge and skills of teachers and staff members and thereby increase the potential of the school to attain its goals and objectives. Sybouts (1994) also pinpoint that staff development programs must be predicted on the beliefs that:

- A school system deliver quality education through quality of its staff and

- Teacher in a continuous learning process. What is more, Travers (1995) lists benefits that staff development programs can offer to the teacher, which are follows:

- To update skills and knowledge in a subject area.

- To keep abreast of societal demands.

- To become acquainted with research on new methods of teaching

- To become equipped with the advances in instructional materials and equipment.

\section{Curriculum Development}

Curriculum development and improvement is another function of school supervisions. Ornstein and Hankins (1998) have stated that the field of curriculum/instruction is directly related to the field of supervision. As the above author put it once curriculum is created we need to "look" at, to supervise, how it is being delivered. Supervisors became curriculum specialists devoting extraordinary amounts of time rewriting, redefining, and strengthening the curriculum (Beach and Reinhartz, 2000). Much of the refinement consisted of individualizing instruction, modifying curriculum, and production of new curriculum guides.

Beach and Reinhartz (2000) further suggested by becoming stakeholder in the curriculum development process, teachers begin to recognized as it one of the vital ingredients of the instructional life of schools and individual 
Manas Ranjan Panigrahi

classroom. Supervisor's role in curriculum development is to promote teacher reflection on key components and to select appropriate concepts to be taught and the methods for implementation. Supervisors and teachers must work to understand the many facets involved in planning and how these facets impact every day instruction and student achievement (Sardo, 1988). In effective schools where there is a strong emphasis on learning and positive student outcomes, principals play an important role.

\section{Evaluation}

Supervisors are expected to assess to what extent the educational objectives are actually being realized, to collect some data in terms of previously stated objectives in which some judgment can be assessed (Brinker hoff and others, 1983; Landers and Myers, 1977). The supervisor helps teachers evaluate their classroom performance, assess their own strengths and weaknesses, and select means of overcoming their deficiencies. Besides as stated in the educational manual of supervision (1995), supervisors are expected to:

a. Create conducive environment to facilitate evaluation activities in the school by organizing all necessary resources for instruction.

b. Coordinate evaluation of teaching learning process and outcome through the initiation of active participation of staff members and the local community at large.

c. Cause the evaluation of schools community relations and on the basis of the evaluation results to improve and strengthen such relations.

Tucker and Stronge (2005) noted from the school models they reviewed that supervisors should consider the context of the following when evaluating teachers in the area of instruction: verbal ability; content of knowledge; pedagogical knowledge; meaningful instruction tied to objectives; monitoring student progress via assessment; using meta-analysis strategies; using data-driven test information; and using student achievement measurements via test.

\section{Problems of Instructional Supervision}

The same way Ogunniy (1984), stated that a supervisor will not be able to carry out instructional evaluation effectively if he/she is not well qualified and trained in techniques of evaluation, a sound up date knowledge of the subject matter, a good organizing skill, and ready
Sci. Technol. Arts Res. J., July-Sep 2012, 1(3): 59-67

to accept teachers idea and interest. Danielson and McGreal (2000) cited limited supervisors experience and a lack of skills as being problems in teacher supervision. He also reported that supervisors did not have enough training in providing constructive feedback while maintaining relationships. Cogan (1973) says that one of the most important factors that affect supervision effectiveness is the "unclarified, ambivalent relation of teachers to supervisors". He goes on to say that "... teachers as a whole saw the supervisor's job as to effectively bar himself from many areas of direct action with the teacher out of fear of arousing resentment and distrust".

\section{Perception of Teachers towards Instructional Supervision}

According to Figueroa (2004) supervision of instruction involves "motivating the teacher to explore new instructional strategies". The teacher must be made aware of the educational goals and standards to be implemented. The observer must be objective during the observation process and maintain confidentiality. It is also important for the observer to provide positive feedback and appropriate resources for the teacher to utilize. Effective supervision should result in growth and learning by the teacher (Duke, 1993). Without growth and learning there is no benefit to being observed. Classroom observation or supervision is seen as a way of gathering information for appraisal purposes. In this way, classroom supervision also improves the quality of children's education by improving the teacher's effectiveness. Jones (1993) also sees it as vital to look at what actually happens within the classroom. Also emphasizes the need to have an agreed criterion so as to avoid arbitrary judgment. Classroom observation appears to work best if set in a cycle of preparation, observation and feedback, hence the need for the supervisor and supervisee to work hand in hand before and even after the observation process.

Kapfunde (1990) says that teachers usually associate instructional supervision with the rating of teachers. He goes on to say that some teachers still perceive supervision as a form of “... inspection and evaluation..." or more popularly "supervision". Teachers may perceive supervision as a worthwhile activity if supervisors give teachers security by backing their judgments even though at times a teacher's judgment can be wrong. Teachers must feel that the supervisor is there to serve them and to help them become more effective teachers. 
Manas Ranjan Panigrahi

\section{Recommendations for Implementation of Instructional Supervision}

Keeping in view of the above discussion, the following Recommendations can be forwarded:

1. Adequate time should be allotted for instructional supervision by school Leaders (Principals, Vice-Principals and Department heads).

2. Supervision of instruction should be scheduled, well-planned and frequently practiced.

3. Instructional supervisors should be relieved themselves from administrative and paper triggered duties.

4. The educational bureau of the region and other officials at various levels should take a wise decision to upgrade knowledge and understandings of school instructional supervisors.

5. Training should be offered to teachers and supervisors to raise awareness on supervision specifically instructional supervision.

6. Magnetic relationship has to be paramount essential between teachers and supervisors and regional education bureau.

7. Decentralizing power of instructional supervision to department heads and senior teachers by minimizing teaching workloads.

8. In order to ensure improved supervision practices, supervisory officials should be acquainted themselves with numerous of supervision models, techniques and principles.

9. Seminar, workshops and conferences should be organized from time to time by the regional educational bureau to update the school supervisory official's focus in instructional supervision.

10. Teachers should be committed to implement the suggestions and feedback offered for them.

11. Establishing system of monitoring and evaluation to follow-up the school instructional supervision practices.

12. The principals and the various head of department should be committed to take part in supervisory role within the school setting as one part of their job to ensure improvement in the quality of program or instruction at all times.
Sci. Technol. Arts Res. J., July-Sep 2012, 1(3): 59-67

\section{REFERENCES}

Acheson, K.A. and Gall, M.D. (1977) Techniques in the Clinical Supervision of Teachers: Pre-service and In-service Applications, New York: Longman Publishers, Pp. 9-11.

Acheson, K.A. and Gall, M.D. (1997) Techniques in the Clinical Supervision of Teachers, (4 Edn.) White Plains, NY: Longman, Pp. 48-60.

Akpotu, N.E. (2006). Problems of Financing Education in Nigeria in Itedjere P.O (Ed) Current Issues in Nigeria Educational System, Abraka: Delsu Printing Press, P.190.

Ali, M.A. (1998). Supervision for Teacher Development: A Proposal for Pakistan, Paris, IIEP/International Institute for Educational Planning Pp. 7-9.

Ball, D. and Mc Diarmid, G.W. (1990) The Subjectmatter Preparation of Teachers, In: R. Houston, Handbook of Research on Teacher Education, New York, Pp. 102-119.

Beach, D. and Reinhartz, J. (2000). Supervisory Leadership: focus on Instruction, Boston, MA: Allyn and Bacon Inc, Pp. 133-134.

Bolin, F. (1986). Perspectives on the Definition of Supervision, Wingspan, 3(2), Pp. 22-29.

Brinker Hoff, R.O. (1983). Program Evaluation: A Practioners Guide for Trainers and Educators, In: Stufflebeam, D.L.; Madaus, G.F. and Kellaghan, T. (1983). Evaluation Models, (Eds.), Chicago University Kluwer Academic Publisher Group, Pp. 33-83.

Bybee, R.W. (2006) The National Science Education Standards: Personal Reflections, School Science and Mathematics 106(2): 57-63.

Calabrese, R.L. and Zepeda, S.J. (1997). The Reflective Supervisor: A Practical Guide for Educators, Larchmont, N.Y: Eye on Education, Pp. 13.

Carron, G. and DeGrauwe, A. (1997) Current Issue in Supervision: A Literature Review, Paris: IIPE/International Institute for Educational Planning, Pp.72.

Cogan, M.L. (1973). Clinical Supervision, Houghton Mifflin Company, Boston: Massachusetts, Pp.10-20.

Costa, A.L. and Garmston, R.J. (1994) Cognitive Coaching: A foundation for Renaissance Schools, Norwood MA: Christopher Gordon, Pp. 2.

Clouse, T.L. (1993). Special Education Teachers' Opinions of Generic and Program Models of Supervision, Doctoral Dissertation, Temple University, Dissertation Abstracts International 54 (07A):2533.

Danielson, C. and McGreal, T.L. (2000). Teacher Evaluation to Enhance Professional Practice. Alexandria, AV: Association for Supervision and Curriculum Development. Available at http://www.ascd.org/cms/index.cfm?TheViewID=34 


\section{Manas Ranjan Panigrahi}

Darling-Hammond, L. and Laughlin, M. (1995) What's at Stake in High Stakes Testing? (Standardized Testing). The Brown University of Child and Adolescent Behavior Letter, January, 2002 sponsored by Manisses Communications Group, Inc. and the Gale Group. Available at http://www.findarticles.com/cf dls/m0537/1 18/831 39498/p1/article.jhtml.

Dornbush, S.M. and Scott, R.J. (1975). Evaluation and the Exercise of Authority, SanFrancisco, CA: JoseyBass, Pp. 121.

Duke, D.L. (1993). Removing Barriers to Professional Growth. Phi Delta Kappan 74(9):702.

Egwunyenga, E.J. (2005) Essentials of School Administration. Benin City: Justice JECO Publishers, Pp. 77

Fanselow, J.F. (1990). Let's see: Contrasting Conversation about Teaching, Pp. 261, In: Richards, J.C. and Nunan, D (Eds.). Second Language Teacher Education, Cambridge: Cambridge University press.

Figueroa, A.N. (2004). Actual and Desired Teacher Attitudes toward Supervision of Instruction and Instructional Strategies in Pedagogical and Curriculum Areas in High and Low Performance Secondary Schools of the Fajardo Educational Region of Puerto Rico, Dissertation at Dowling College (UMI No -in process)

Fikadu Atra (1992). The State of Educational Inspection with Reference to Some Selected Senior Secondary Schools in Illibabor Administration Region, Ph.D Dissertation, Adis Ababa University, Ethiopia: Adis Ababa.

Fraser, K. (1980). Supervisory Behaviour and Teacher Satisfaction, Journal of Educational Administration 18(2): 224-227

Frazze, B. and Rudnitski, R.A. (1995). Integrated Teaching Methods: Theory, Classroom Applications and Field-based Connections. Albany, NY: Delmar Publishers, Pp. 120

Fullan, M. (2006). Leadership \& Sustainability, Systems Thinkers in Action. Thousand Oaks, CA Sage Publications.

Gebhard, J.G. (1990) Models of Supervision: Choices, Pp. 263-269. In: Richards, J.C. and Nunan, D (Eds.), Second Language Teacher Education, Cambridge: Cambridge University press.

Glanz, J. and Behar-Hornstein, L.S. (2000). Paradigm Debates in Curriculum and Supervision: Modern and Postmodern Perspective, Westport, CT: Bergin and Garvey, Pp.190-211.

Glatthorn, A.A. (1990). Supervisory Leadership: Introduction to Instructional Supervision. New York, NY: HarperCollins Publishers, Pp. 177-179.

Glickman, C.D. (1990) Right Question, Wrong Extrapolation: A Response to Duffey's 'Supervision for Results'. Journal of Curriculum and Supervision 6(1): 39-40
Sci. Technol. Arts Res. J., July-Sep 2012, 1(3): 59-67

Glickman, C., Gordon, S. and Ross-Gordon, J. (1997). Supervision and Instructional Leadership: A Developmental Approach (6th Edn). Boston, MA: Allyn and Bacon, Pp. 10-11.

Glickman, C.D. (1998). Supervision of Instruction: $A$ Developmental Approach (2 ${ }^{\text {nd }}$ Edn). Toronto, Canada: Allyn and Bacon, Pp. 253-255.

Glickman, C., Gordon, S. and Ross-Gordon, J. (2003). Supervision and Instructional Leadership: A Developmental Approach. Boston MA: Allyn \& Bacon, P. 6.

Goker, S.D. (1998). A School Based Management and Supervision Models ESL School Turkey. Gazima: USA PIC, Pp. 59-63.

Goldhammer, R. (1969). Clinical Supervision: Special Methods for the Supervision of Teachers. New York, NY: Holt, Rinehart and Winston, Pp. 10-19.

Goldhammer, R., Anderson, R. and Krajewski, R. (1980). Clinical Supervision: Special Methods for the Supervision of Teachers ( $2^{\text {nd }}$ Edn). New York, NY: Holt, Pp.19.

Harrison, B.M. (1968). Supervision Behaviours in Education ( $3^{\text {rd }}$ Edn). New Jersey: Prentice Hall, Pp. $1-2$

Huling-Austin, L. (1990). Teacher Induction Programs and Internships. In R. Houston (Ed.), Handbook of research on teacher education, Pp. 535-548. New York: Macmillan.

Jones, K. (1993) Educational Management V: Human Resources Management EMH 500A 2004 Technikon, Pretoria Journal of Education Administration 18(2):224-227.

Joyce, B. and Showers, B. (1982). The Coaching of Teaching, Educational Leadership 40(8):4-10

Juska, N. (1991) Case Studies: Windows into Clinical Supervision. Educational Leadership, 50(1), 52-56.

Kapfunde, C.L. (1990). Clinical Supervision in the Zimbabwean Context. Harare Zimbabwe Publishing House.

Landers, T.J. and Myers, J.G. (1997). Essentials of School Management. Philadelphia: W.B.S. Sounders Company, Pp. 214-215.

Lortie, D.C. (1975) School Teacher: A Sociological Study. Chicago, IL: University of Chicago Press.

Lovell, J.T. and Wiles, K. (1983). Supervision of Better Schools $\left(5^{\text {th }}\right.$ Edn), New Jersey: Prentice Hall Inc, Pp. 154-159

Lucio, W.H. and John, M.N. (1979). Supervision in Thought and Action ( $\left.3^{\text {rd }} E d n\right)$, New York: Mc Graw Hill Book Company, Pp. 79.

Marks, J.R. (1985) Handbook of Educational Supervision ( $3^{\text {rd }}$ Edn), New York Boston: Allyn and Bacon Inc. Pp. 91-200.

Mcgrath, M.J. (2000). Human Dynamics of Personnel Evaluation. The School Administrator 34-38. 
Manas Ranjan Panigrahi

McGreal, T.L. (1995). Impact of New Evaluation Process on Teacher Involvement and Teacher Reflection. A report to the Illinois Association for Supervision and Curriculum Development. Champaign, IL: The University of Illinois.

Ministry of Education, (1987). Educational Supervision Manual and Practice, Ethiopia: Addis Ababa, 4(4): 21-26.

Mohanty, J. (1994). Educational Administration and School Management, New Delhi, India: Deep and Deep Publication, Pp. 176-193.

Musazi, J.C. (1987) Theory and Practice of Educational Administration. Nigeria: McMillan, Pp. 196.

Nakpodia, E.D. (2006) Educational Administration: A New Approach (2 ${ }^{\text {nd }}$ Edn), Warri: Jonokase Publishers, Pp. 181-215.

Neagley, R.L. and Evans, D.N. (1964). Handbook for Effective Supervision of Instruction. New Jersey: Prentice Hall. pp. 20

Ogden, L. (1998). A Better Way to Supervise. Thrust for Educational Leadership 27(7): 20-21.

Ogunniyi, M.B. (1984). Educational Measurement and Evaluation. Nigeria: Longman Group Ltd. P. 25.

Onoyase, D. (1991) Theory and Practice of Educational Administration. Warri: Okienriete Publishers Pp. 151-156.

Ornstein, C.A. and Hankins, F.P. (1998) Curriculum Foundations, Principles and Issues $\left(3^{\text {rd }} \mathrm{Edn}\right)$. Boston: Allyn and Bacon Inc. P. 98.

Pajak, E. (1993). Conceptions of Supervision and Leadership: Change and Continuity. In: Cawelti, G. (Edn.). Challenges and Achievements of American Education, 1993 ASCD Yearbook. Alexandria, VA: Association for Supervision and Curriculum Development. 1703 North Beauregard Street, Alexandria, VA, 22311-1714.

Parakash, R. (2005). Methods of Educational Research. New Delhi: AJay Verma Common Wealth, Pp. 235.

Reavis, C.A. (1978). Teacher Improvement through Clinical Supervision ( $3^{\text {rd }}$ Edn). Phi Delta Kappa, Foundation Bloomington, Indiana, Pp. 136.

Reiman, A.J. and Thies-Sprinthall, L. (1998). Mentoring and Supervision for Teacher Development. New York: Longman.

Richardson, M.D., Short, P.M. and Prickett, R.L. (1993). School Principals and Change. New York, NY: Garland Publishing.

Robert, D.K. and Peter, J.B. (1989). A Design for Instructional Supervision. Spring Field III: Charles C: Thomas, P. 11.

Sardo, B.D. (1988) Twelve Middle-School Teachers' Planning. The Elementary School Journal 86(35): 69-87.
Sci. Technol. Arts Res. J., July-Sep 2012, 1(3): 59-67

Sergiovanni, T.J. (1985). Landscapes, Mindscapes, and Reflective Practice in Supervision. Journal of Curriculum and Supervision 1(1):11.

Sergiovanni, T.J. and Starratt, R.J. (1993). Supervision: A Redefinition ( $7^{\text {th }}$ Edn). New York, NY: McGraw-Hill, Pp. 20-21.

Sergiovanni, T.J. and Starratt R.J. (1998) Supervision: A Redefinition ( $6^{\text {th }}$ Edn). New York: McGraw-Hill, Pp. 39.

Sergiovanni, T.J. (2006). Principalship: A Reflective Practice Perspective. Boston: Pearson.

Spears, H. (1995). Improving the Supervision of Instruction. New York: NY American Book, P. 34.

Starratt, R.J. (1997). Should Supervision Be Abolished?. In: Jeffrey Glanz and Richard F. Neville (Edn.), Educational Supervision: Perspectives, Issues, and Controversies, Norwood, MA: Christopher Gordon Publishers.

Sullivan, S. and Glanz, J. (2000). Supervision that Improves Teaching. Thousand Oak CA: Corwin Press, Pp. 22.

Syoubts, W. (1994). The Training and Development of School Principal. New York, USA: Green Wood Press, Pp. 257-262.

Tarrant, T. and Newton, C. (1992). Managing Change in Schools: Practical Hand Book. London: Route Ledge, Pp. 142-146.

Temesgen M. (1998). Principals Instructional Effectiveness and Influencing Factors in Secondary School. MA Thesis, Adiss Ababa University, Ethiopia.

Travers, P.D. (1995). Foundation of Education. New York, USA: Allyn and Bacon Co., Pp. 254-255.

Tucker, P.D. and Stronge, J.H. (2005). Linking Teacher Evaluation and Student Learning. Alexandria, VA: Association for Supervision and Curriculum Development.

Ukeje, O.B. (1992). Educational Administration. Nigeria: Fourth Dimension Publishing Cap. Ltd. 15: 37-38

Wanzare, Z. and DaCosta, J.L. (2000). Supervision and Staff Development: Overview of the Literature. NASSP Bulletin, 84(618), 47-54.

Wiles, J. and Bondi, J. (2000). Supervision: A Guide to Practice. NJ: Prentice Hall, P. 8.

Zepeda, S. (2007). Instructional Supervision: Applying Tools and Concepts ( $2^{\text {nd }}$ Edn). Larchmont, NY: Eye on Education.

Zepeda, S.J. and Ponticell, J.A. (1998) At CrossPurposes: What Do Teachers Need, Want, and Get from Supervision?, Journal of Curriculum and Supervision. 14(1):68-87. 